\title{
Fiscal Policy to Support the Development of Seaweed as Renewable Energy in Indonesia
}

\author{
Tri Wibowo and Purwoko
}

\begin{abstract}
Indonesia is facing a huge pressure from increasing the demand of energy due high economic growth and a growing middle income population. The increase in oil consumption cannot be matched by domestic production, since 2004 Indonesia has been recorded as an importer of crude oil. Meanwhile, the development of new and renewable energy has not gone as expected. Indonesia as an archipelago with a coastline of more than 80 thousand kilometers has great potential in developing alternative energy made from seaweed raw materials. Abundant seaweed production in Indonesia has the potential to be developed as an alternative energy in the future. The advantage of seaweed as a renewable energy comes from the relatively fast production of seaweed, there is no competition in agricultural land, and low emissions (clean energy). This study aims to determine the potential of seaweed as a renewable energy source and find alternative fiscal policies for its development into renewable energy, especially from seaweed. The methodology used is descriptive exploration in the form of descriptions and explanations about the phenomena that occur in the development of seaweed as an alternative to renewable energy in Indonesia. Incentives for seaweed farmers can be provided through government spending in the form of subsidies or social assistance for planting seaweed that absorbs carbon. Meanwhile, seaweed bioethanol producers can be given tax incentives for creating low-emission fuels especially those made from seaweed.
\end{abstract}

Index Terms-Alternative energy, seaweed, fiscal policy.

\section{INTRODUCTION}

The high and stable economic growth and population of 260 million of Indonesia, bringing consequences to the high demand for energy. In the past few decades, Indonesia was an oil exporter. But with increasing consumption, Indonesian oil production is no longer able to meet domestic needs. Since 2004, Indonesia has been a net oil importer. Facing these challenges, the Government of Indonesia is very concerned about energy development in the future.

The direction of Indonesia's energy mix policy has been regulated through Government Regulation No. 79 of 2014 concerning the National Energy Policy, Indonesia's energy supply sources are directed from fossil energy to renewable energy. Renewable energy policies in Indonesia are directed at green energy sources. But in its implementation, the development of energy sourced from renewable energy has not proceeded as expected. In 2018 EBT only contributed 8.6 percent. The renewable energy target in 2025 is expected to

Manuscript received November 26, 2019; revised January 14, 2019. This work was supported in part by the Fiscal Policy Agency, Ministry of Finance on the Republic of Indonesia.

The authors are with the Center of State Revenue Policy, Fiscal Policy Agency, Ministry of Finance of the Republic of Indonesia (e-mail: denmase.purwoko@gmail.com,3wibowo@gmail.com). contribute 23 percent [1].

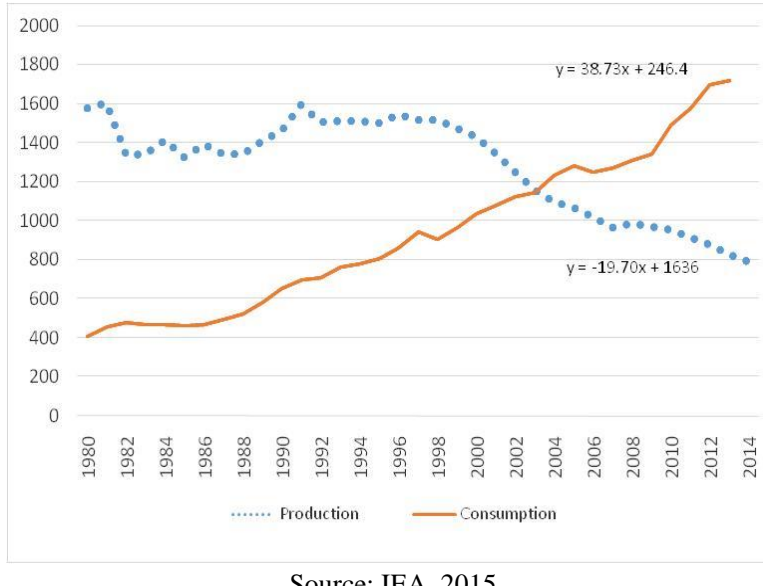

Fig. 1. Oil production and comsumption (thousand barrel/day).

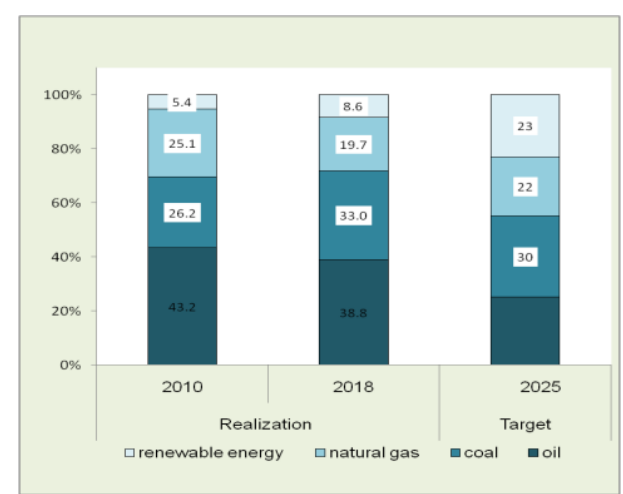

Source: Ministry of Energy and Mineral Resources (MEMR) Fig. 2. Target and realization supply energy mix Indonesia.

\section{RENEWABLE ENERGy Potential IN INDONESIA}

Indonesia began adopting biofuels policy at national level in 2006 by issuing Regulation governing the procurement and usage of biofuels. In support of Regulation 1, Presidential decree 20/2006 established a National Biofuel Development Team, responsible for supervising the implementation of biofuel programs and creating a blueprint for biofuels development. According to the blueprint, biofuel development is aimed to (1) alleviate poverty and unemployment, (2) drive economic activities through biofuel procurement and (3) reduce domestic fossil fuel consumption. This regulation was followed by Indonesia's House of Representative (DPR), which passed Energy Law (UU $30 / 2007$ ) to strengthen regulations prioritizing the use of renewable energy. [2]

These benefits are clear for developed countries, but are likely to have an even stronger impact if it is also used in developing countries, especially among the rural poor. Algae (co-)production for bioenergy seems to have various benefits 
compared to the production of first generation biofuels from traditional food crops as soy or palm oil. [3] Microalgae are sunlight-driven cell factories that convert carbon dioxide to potential biofuels, foods, feeds and high-value bioactives . [4] Microalgae have the capability of producing hydrogen, lipids, hydrocarbons, and carbohydrates, which can be converted into a variety of fuels. [5]

As an archipelagic country and has a coastline of around 80 thousand $\mathrm{Km}$, Indonesia has enormous potential in developing alternative energy (biomass) made from seaweed raw materials. Abundant seaweed production in Indonesia has the potential to be developed as an alternative energy in the future. The advantage of seaweed as a renewable energy is the production of seaweed which is relatively fast and there is no land competition due to the development of the sea, and low emissions (clean energy).

FAO [2] reports that Indonesia ranks the 2nd largest seaweed production in the world after China. Indonesia's seaweed production reached 38 percent ( 11.3 million tons) while China reached 47 percent (14 million tons) of total world seaweed production of 29.5 million tons in 2015.Compared to other land plants, the potential of seaweed is able to produce bioethanol far greater than other plants. This of course makes seaweed as a very potential raw material for bioethanol manufacturing. Corn is only able to produce bioethanol of 2 thousand liters per Ha per year, sugar cane produces nearly 7000 liters of bioethanol per Ha per year. Meanwhile, seaweed is able to produce 23,000 liters of bioethanol per hectare per year, or more than 10 times compared to bioethanol produced from corn per hectare. During 2018, Indonesia's fuel consumption is estimated to reach 75 million kilo liters.

The United States Department of Agriculture (USDA, 2018) reports that the Development of New and Renewable Energy in Indonesia, especially from biofuels in form of bioethanol extracted from molasses (molasses) is still relatively stagnant. In 2009 bioethanol production amounted to 172 million liters, up to 195 million liters in 2017. Bioethanol made from sugar cane in July 2018 will cost Rp. 9,900 per liter. Much higher than the premium per liter for Rp. 6550. Meanwhile, biodiesel derived from CPO has developed quite rapidly due to government policy support. In 2009 its production amounted to 330 million liters, up to 3,400 million liters in 2018. In term of price, one liter biodiesel in July 2018 costs Rp. 7,950 per liter, more expensive than the price of diesel (diesel) per liter which costs only Rp. 5,150. [6]

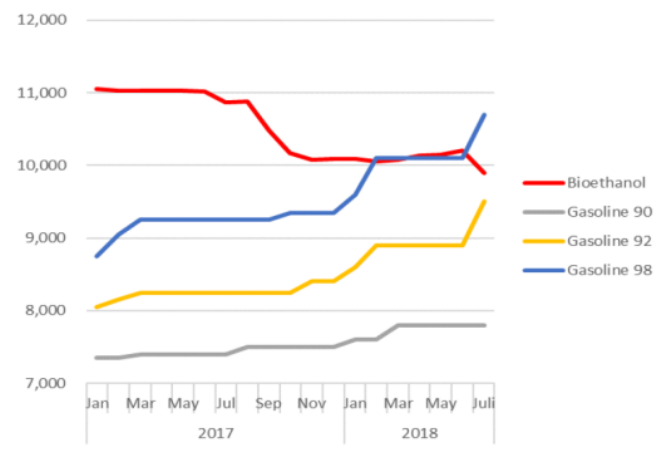

Source: Ministry of Energy and Mineral Resources (MEMR) Fig. 3. The price of bioetahanol and gasoline (Rp./liter).

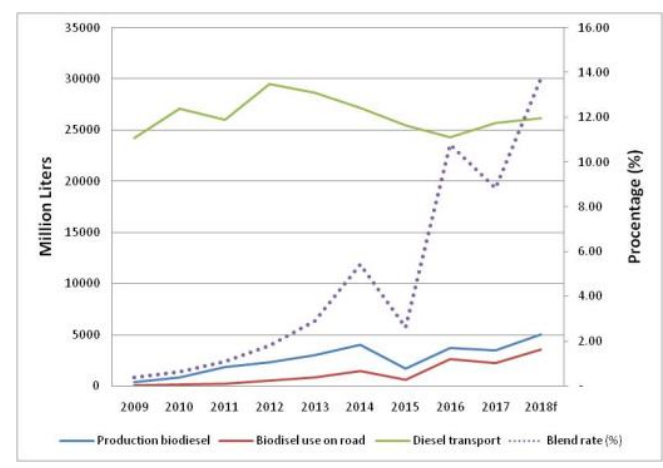

Fig. 4. Market penetration biodiesel.

\section{Fiscal POLICY SUPPORT to DEVElOPMENT RENEWABLE ENERGY}

\section{A. Fiscal Policy for in Several Countries}

To increase the use of biofuels, several countries have developed various fiscal policies. Those policies are summarized as follows:

TABLE I: POLICY FOR BIOFUELS

\begin{tabular}{|c|c|}
\hline Country & Fiscal Policy \\
\hline Australia & $\begin{array}{l}\text { subsidize ethanol producers or biodiesel } \\
\text { producers by granting an amount } \\
\text { equivalent to the excise duty, which is } \\
0.38143 \text { Australian Dollar per liter of } \\
\text { ethanol/boidisel }\end{array}$ \\
\hline China & $\begin{array}{l}\text { The Ministry of Finance of China } \\
\text { intends to abolish refund of the value } \\
\text { added tax and impose a } 5 \% \text { consumption } \\
\text { tax on production of grain based } \\
\text { ethanol. }\end{array}$ \\
\hline India & $\begin{array}{l}\text { Concessional excise tax of } 16 \% \text { is } \\
\text { imposed on ethanol, biodiesel is } \\
\text { exempted from excise duty. No other } \\
\text { central taxes and duties are proposed to } \\
\text { be levied on ethanol and biodiesel. } \\
\text { The Government of India offers } \\
\text { subsidized loans through sugarcane } \\
\text { development funds to sugar mills for } \\
\text { establishing an ethanol production unit. }\end{array}$ \\
\hline Japan & $\begin{array}{l}\text { Given the country's limited land } \\
\text { resources, the Japanese government's } \\
\text { strategy,is to focus determinedly on } \\
\text { cellulosic ethanol or algae derived } \\
\text { biodiesel as the future for Japan's } \\
\text { biofuel production }\end{array}$ \\
\hline
\end{tabular}

Source: Kaoru Yamaguchi [7]

\section{B. Fiscal Scheme for Seaweed Support}

Regulations related to fiscal policy for renewable energy in Indonesia are regulated in Peraturan Menteri Keuangan (PMK) / Regulation the Minister of Finance:

TABLE II: FISCAL POLICY REGULATION FOR BIOFUELS IN INDONESIA

\begin{tabular}{|c|c|}
\hline Regulation & Fiscal Policy \\
\hline $\begin{array}{l}\text { PMK Number } \\
\text { 21/PMK.011/2010 } \\
\text { Provision of tax and customs } \\
\text { facilities for activities related to } \\
\text { utilisation of renewable energy }\end{array}$ & $\begin{array}{l}\text { fiscal policy incentives for business } \\
\text { entities working on the development of } \\
\text { new and renewable energy, including } \\
\text { accelerated amortisation. Accelerated } \\
\text { amortisation may reduce income tax } \\
\text { significantly }\end{array}$ \\
\hline $\begin{array}{l}\text { PMK Number } \\
\text { 24/PMK.011/2010 } \\
\text { Facilities for tax and custom for } \\
\text { activities related to utilisation }\end{array}$ & $\begin{array}{l}\text { Facilities for tax and custom for } \\
\text { activities related to utilisation of } \\
\text { renewable energy : } \\
\text { a. Income tax facilities; }\end{array}$ \\
\hline
\end{tabular}




\begin{tabular}{l|l}
\hline of renewable energy & $\begin{array}{l}\text { b. Value added tax facilities; } \\
\text { c. Import duty Facilities; } \\
\text { d. government-borne tax facilities. }\end{array}$ \\
\hline Source : Regulation the Minister
\end{tabular}

Based on the government target for biofuels, it is projected that bioethanol and biodiesel demand will reach $13621.2 \mathrm{ktoe}$ and $8298.3 \mathrm{ktoe}$ respectively in 2035 . However, it should be noticed that since the projected demand is only that from road transport, the real demand might be bigger because biofuels are also likely to be used in other sectors including industry sector and power generation. In Indonesia, cassava and sugar cane (molasses) are the major feedstocks for bioethanol production. Based on these two crops, the supply potential of bioethanol in 2035 is estimated to reach 2320.9 ktoe rising moderately from 1765.7 ktoe in 2010. [7]

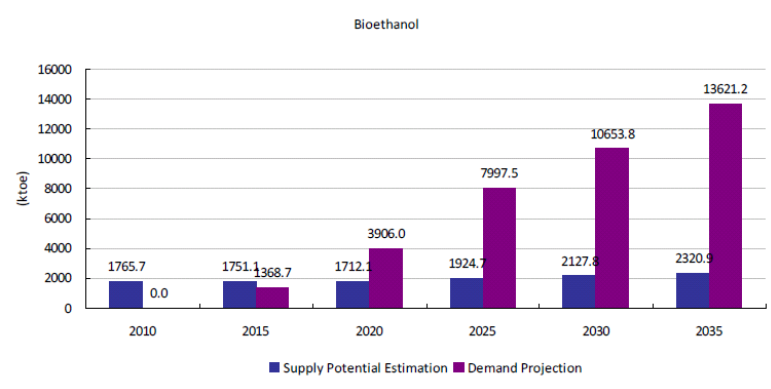

Source: Kaoru Yamaguchi [7]

Fig. 5. Supply and demand bioethanol Indonesia.

Fiscal policy for developing bioethanol from seaweed needs to consider the supply aspects of seaweed farmers. By planting seaweed, seaweed farmers have helped the government reduce carbon emissions. It is estimated that the expansion of seaweed farm can absorb carbon up to 83,000 metric tons per $\mathrm{km} 2$. This capability is far greater than forests on land that absorb 30,000 metric tons of carbon per $\mathrm{km} 2$ in the form of wood. From the industry side, by managing seaweed waste (biomass) the industry has helped to manage the environment so that it is feasible to obtain fiscal incentives in the form of tax reductions.

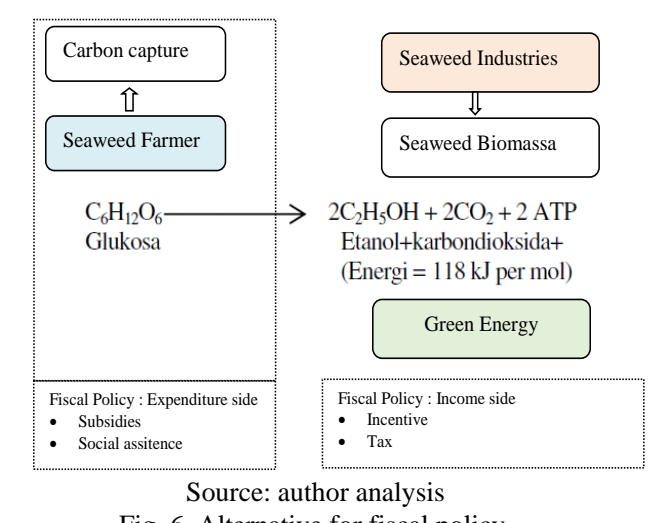

Fig. 6. Alternative for fiscal policy.

The Government of Indonesia in 2019 has issued Regulation of the President of the Republic of Indonesia Number 33 of 2019 concerning Road Map for the Development of the National Seaweed Industry in 2018-2021. With this regulation, it is hoped that the development of a reliable, competitive and sustainable seaweed industry will increase the income of coastal communities, border areas and disadvantaged areas. [9]

This regulation has not specifically mentioned the direction of developing seaweed-based bioethanol. However, with the development of the domestic seaweed industry will be available waste / seaweed biomass which is the basis of the development of bioethanol. This regulation is a guidelines for ministers and heads of non-ministerial institutions to establish sectoral policies and work plans related to the development of the national seaweed industry in their respective fields of duty.

The main problem in developing seaweed bioethanol is the high selling price of bioethanol. [10] The government can provide subsidies for the development of seaweed bioethanol with conventional fuels. For example E10 which is 10 percent from bioethanol and 90 percent from premium fuel. The subsidy mechanism can be used to calculate the price difference between bioethanol and premium. The government bears the E10 subsidy per liter of $=10$ percent $\mathrm{x}$ (price difference).

For example: the price of gasoline is Rp. 6,500 / liter, Ethanol of Rp. 10,000 / liter. For ethanol mix E10 (10 percent ethanol content and 90 percent gasoline) the subsidy per liter is $10 \% \times(10,000-6500)=$ Rp. 350 per liter.

\section{CONCLUTION AND RECOMMENDATION}

Oil demand especially for transportation in Indonesia will increase. The government needs to immediately develop biofuels in the country so that the lack of oil supply in the future will not be wider. Indonesia has good potential in the development of seaweed in the future. The development of seaweed as a renewable energy has advantages over other land plants because there is no land competition, high carbon emission absorption, and and increase the income of seaweed farmers.

To accelerate the development of biofuels from seaweed, it needs supporting fiscal policies. From the farmer side, policies can be provided through subsidies or social assistance. As for the industry, fiscal incentives can be given in the form of tax incentives.

\section{CONFLICT OF INTEREST}

This article is the opinion of the author not representing the policy views of the institution where the author works. The author states there is no conflict of interest in writing this article with any party.

\section{AUTHOR CONTRIBUTIONS}

This article is mostly done by Tri Wibowo starting from ideas to writing articles. Purwoko's contribution was mainly in library research and discussion. Both authors have agreed to the final version of the article.

\section{ACKNOWLEDGMENT}

The author thanks to Mr. Suahasil Nazara as Head of the Fiscal Policy Agency - Ministry of Finance of the Republic of Indonesia, who has provided both motivation and financial 
support. Acknowledgments also the authors convey to Mr. Hidayat Amir who has provided input and correction for the improvement of this article.

\section{REFERENCES}

[1] Indonesia: Government Regulation Number 79/2014 Concerning the National Energy Policy, "National Energy Policy (KEN), as formalized in Indonesia Government regulations number 79/2014," 2014-2050.

[2] FAO, "The global status of seaweed production, trade and utilization," 2018.

[3] FAO, "Review paper Algae-based biofuels: Applications and co-products," 2010.

[4] Y. Chisti, "Biodiesel from microalgae," Biotechnology Advances, vol. 25, pp. 294-306, 2007.

[5] IEA, Tracking Clean Energy Progress 2014, International Energy Agency, 2014

[6] USDA ${ }^{\mathrm{b}}$, Indonesia Expands Biodiel Mandate, Gain Report Number: ID1826, Global Agriculture Information Network, USDA Foreign Agriculture Service, 2018.

[7] K. Yamaguchi, "Study on Asia potential og biofuel market," ERIA Research Project Report 2012, no. 25, 2013.

[8] MOF, Reguation of The Minister of Finance Number 21/PMK011/2010.

[9] Regulation of the Presiden of the Republic of Indonesia number 33/2019 concerning Roadmap for Development of The National Seaweed Industry in $2018-2021$.

[10] MOF, Fiscal Policy Options for the Energy Sector Support of Indonesia's Sustainable Development, Fiscal Policy Agency Ministry of Finance Republic of Indonesia, 2015.
Copyright $(C 2020$ by the authors. This is an open access article distributed under the Creative Commons Attribution License which permits unrestricted use, distribution, and reproduction in any medium, provided the original work is properly cited ( $\underline{\mathrm{CC} \mathrm{BY} 4.0})$.

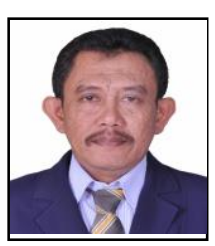

Tri Wibowo was born in Yograkarta, Special Province of Yogyakarta, Indonesia, on August 19, 1966. Completed his masters in management in Jakarta in 1996. Now, he works as a researcher in the Fiscal Policy Agency, Ministry of Finance of the Republic of Indonesia, since 2000. Previously served in the directorate general of budget from 1997 to 1999. Tri Wibowo is conducting research on price stability and rice availability in Indonesia.

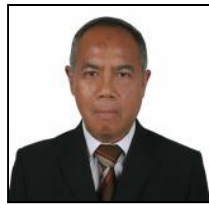

Purwoko was born in Ngawi, a small town in the province of East Java, Indonesia, on September 10, 1955. He completed his MBA program at Saint Mary's University in Halifax Canada in 1996.

Currently, he works as a researcher in the Fiscal

Policy Agency, Ministry of Finance of the

Republic of Indonesia, since 2000. Previously, he worked as a programmer and systems analyst at the Ministry of Finance Computer Center, from 1977 to 1999. Purwoko, SE., MBA is conducting research on tax incentives for enhancing the competitiveness of domestic industry, especially in sugar and meat industry. 